\title{
Problematic issues of quality, certification and tests of fire-fighting technical production
}

\author{
Tatiana Eremina $^{1, *}$, Mikhail Nesterov ${ }^{2}$, Dmitry Korolchenko ${ }^{1}$, and Anatoly Giletich ${ }^{3}$ \\ ${ }^{1}$ Moscow State University of Civil Engineering, 26, Yaroslavskoe shosse, 129337, Moscow, Russia \\ ${ }^{2}$ Department of Supervisory Activitiy and Offensive Activity of EMERCOM of Russia, 1, Vatutina \\ str., 121357, Moscow, Russia \\ ${ }^{3}$ Fire Safety in Construction Ltd, 1, Gigant str., 140200, Voskresensk, Moscow Region, Russia
}

\begin{abstract}
The paper analyzes the compliance of products with the requirements of the "Technical Regulations on Fire Safety Requirements". In the conditions of rapid growth of industry, production and output of products using new technologies with the use of new substances and materials, there is a need for the state and society to respond adequately to all kinds of risks that may arise in the use of products, especially if such products are subject to mandatory requirements. One of the types of such products is fireproof paints, varnishes and coatings - Fire Retardant Coatings (hereinafter - FRC). Application of FRC is based on increasing the fire resistance of building structures to the level regulated by the existing regulations depending on the degree of fire resistance of the building. Frequently, problems with FRC quality are only detected at the stage of checking the performance of fire protection works when applying FRC which do not meet the fire safety requirements.
\end{abstract}

\section{Introduction}

In accordance with the Federal Law [1], fire protection substances and materials must comply with fire safety requirements.

However, at present in Russia there is an excessively high number of certification bodies and testing laboratories (centers), performing work to confirm the compliance of products with the requirements of the "Technical Regulations on Fire Safety Requirements" compared to other countries.

In the international practice (Great Britain, Europe, USA) there is a single register for exchange of information on detected violations in the confirmation of compliance of products with fire safety requirements [2-7].

\section{Objectives of the research}

The research was conducted to improve the mechanism of quality control of the fire safety products - FRC in particular.

\footnotetext{
*Corresponding author : ikbs@mgsu.ru
} 


\section{Tasks}

Objectives of the study: analysis of problematic issues in order to introduce mechanisms of notification of certification bodies performing work on confirmation of conformity of fire safety products to improve fire safety of facilities of any purpose (notification (from Latin notificare - to make known) - in international law - official notice by the Ministry of Foreign Affairs to an international organization or its official); development of methods of identification, their registration and methods of control of products that have undergone the confirmation procedure in Russia.

\section{Analytics}

Works on confirmation of product compliance with the requirements of the "Technical Regulation on Fire Safety Requirements" are carried out by 3 certification bodies and 12 testing laboratories (centers), of the Ministry of Emergency Situations of the Russian Federation, including those that enjoy public recognition and the trust of experts:

- Certification body of the Federal State Budget Institution "All-Russian Research Institute of Fire Protection of the Ministry of Emergency Situations of Russia";

- Certification body of the Federal State Budgetary Educational Institution of Higher Professional Education "Academy of the State Firefighting Service of the Ministry of Emergency Situations of Russia";

- Certification body of the Federal State Budgetary Educational Institution of Higher Education "Saint-Petersburg University of the State Firefighting Service of the Ministry of Emergency Situations of Russia";

- As well as 25 certification bodies and 34 testing laboratories (centers), third-party organizations, including the testing laboratory of the Federal State Budgetary Educational Institution of Higher Education "Moscow State Construction University".

Currently, about $40 \%$ of certification bodies and testing laboratories (centers) operate in Moscow.

For the past period of 2018 the confirmation of conformity of products to the requirements of the Federal Law of 22.07.2008 № 123-FZ "Technical Regulations on Fire Safety Requirements" was carried out by 27 product certification bodies (hereinafter - the $\mathrm{CB}$ ), of them: $3 \mathrm{CBs}$, subordinated to the Ministry of Emergency Situations of Russia and 24 third-party CBs.

The total number of certificates of conformity issued by the CBs for 2018 amounted to 3379 pieces. (same period of the previous year (SPPY) - 4977 pcs., $-47.3 \%$ ), of which:

488 NSE subordinated to the Ministry of Emergency Situations of the Russian Federation. (SPPY - 679 pcs., -39.1\%);

Other operating systems - 2891 pcs. (SPPY - 4298 pcs., $-48.7 \%$ ).

It should also be noted that a large number of conformity certificates are issued under the scheme $5 \mathrm{c}$ of the Technical Regulations on the basis of QMS certificates (quality management certificate) by QMS certification bodies that do not have accreditation in the national accreditation system, which is a violation of current legislation.

Also, in accordance with paragraph 2.3. of the Order of the Ministry of Economic Development of the Russian Federation of 28.08.2017 № 437 "On Approval of Risk Indicators of Violation of Mandatory Requirements by Accredited Persons", a twofold or more increase in the number of certificates of conformity issued by an accredited person in the national accreditation system per unit of time in comparison with the previous period is a ground for conduction of state control measures by the Federal Service for Accreditation. 
Table 1. Distribution of certification bodies and testing laboratories (centers) by federal districts of the Russian Federation.

\begin{tabular}{|c|c|c|c|c|c|}
\hline \multirow[b]{2}{*}{ № } & \multirow[b]{2}{*}{$\begin{array}{l}\text { Federal } \\
\text { District }\end{array}$} & \multicolumn{2}{|c|}{$\begin{array}{l}\text { Number of accredited } \\
\text { certification bodies }\end{array}$} & \multicolumn{2}{|c|}{$\begin{array}{c}\text { Number of accredited test } \\
\text { laboratories (centers) }\end{array}$} \\
\hline & & Total & $\begin{array}{c}\text { Of them } \\
\text { belonging to } \\
\text { Ministry of } \\
\text { Emergency } \\
\text { Situations of } \\
\text { Russia } \\
\end{array}$ & Total & $\begin{array}{c}\text { Of them } \\
\text { belonging to } \\
\text { Ministry of } \\
\text { Emergency } \\
\text { Situations of } \\
\text { Russia } \\
\end{array}$ \\
\hline 1. & North-West & 2 & 1 & 3 & 1 \\
\hline 2. & Central & 9 & 1 & 11 & 3 \\
\hline 3. & Volga & 1 & 0 & 3 & 1 \\
\hline 4. & Ural & 0 & 0 & 2 & 2 \\
\hline 5. & South & 1 & 0 & 5 & 3 \\
\hline 6. & Siberian & 3 & 0 & 3 & 0 \\
\hline 7. & Far East & 0 & 0 & 0 & 0 \\
\hline 8. & $\begin{array}{c}\text { North } \\
\text { Caucasus }\end{array}$ & 0 & 0 & 0 & 0 \\
\hline 9. & Moscow City & 12 & 1 & 19 & 2 \\
\hline & Total: & 28 & 3 & 46 & 12 \\
\hline
\end{tabular}

In Russia, fire safety requirements for general purpose products and firefighting equipment are currently established by the Technical Regulations [1].

Technical regulations [1] are adopted in accordance with [8] in order to protect life, health, property of citizens and legal entities, state and municipal property from fires. They define the main provisions of technical regulations in the field of fire safety and establish general fire safety requirements to the protected items (products), including buildings and structures, production facilities, fire protection products and general purpose products. Article 136 of the Technical Regulations [1] establishes the requirements for information on fire safety of fire protection means, according to which the technical documentation for fire protection means must contain specific information on the scope of their application, fire hazard, method of surface preparation, types and grades of soils, method of application on the protected surface, drying conditions, fire protection efficiency of these means, method of protection from adverse climatic effects, conditions and service life of fire protection means, as well as safety measures at their application.

In accordance with Article 146 of the Technical Regulations [1] fire protection means are subject to mandatory conformity assessment in the form of certification.

The Order [9] approves the List of national standards containing rules and methods of research (tests) and measurements, including the rules of sampling, necessary for the application and implementation of the Technical Regulations and conformity assessment.

The abovementioned list contains national standards, according to which the procedure of fire protection conformity assessment is carried out.

It should also be noted that the confirmation of compliance of fire protection means has some peculiarities.

In accordance with Article 150 of the Technical Regulations [1] for the certification the applicant shall submit to the accredited certification body the accompanying documents, which shall specify the main indicators, scope and methods of application of the fire protection means.

Test reports of testing laboratories shall contain the values characterizing the fire protection efficiency of fire protection means, including various types of their application, described in the accompanying documents. 
The following special characteristics of fire protection means shall be reflected in the certificate:

1) name of the fire protection means;

2) the value of fire protection efficiency established during the tests;

3 ) types, grades, thickness of layers of ground, decorative or weatherproof coatings used in combination with this means of fire protection during certification tests;

4) thickness of fire protection coating of fire protection means for the established fire protection efficiency.

Fire protection labels affixed by manufacturers to products may only include information confirmed by certification.

Meanwhile, in the period from 01.01.2017 to 31.12.2018, the total number of certificates of conformity issued to the requirements of the Technical Regulations [1] amounted to 8,356 , of which 1,167 certificates of conformity were issued by certification bodies subordinate to the Ministry of Emergency Situations of Russia, which is $14 \%$ of the total number.

At the same time, a number of technical regulations of the Customs Union and the Eurasian Economic Union (hereinafter - the Union) were adopted, which also contain fire safety requirements for products. At the same time, certain technical regulations of the Union do not contain a full range of fire safety requirements, but are established for certain product characteristics.

This may be the reason for the release into circulation of unsafe products, as well as the development of unfair competition among manufacturers and public organizations.

It should also be noted that on June 23, 2017 the Council of the Eurasian Economic Commission adopted the Technical Regulation of the Eurasian Economic Union "On Requirements for Fire Safety and Fire Fighting Facilities" (TR EAEU 043/2017) No. 40. Its provisions will become mandatory from January 1, 2020.

The abovementioned technical regulations of the Eurasian Economic Union established requirements to more than 100 names of fire protection products.

At present, the Eurasian Economic Commission is discussing the lists and the program of development of interstate standards establishing fire safety requirements for fire protection products and methods of their testing, taking into account the modern achievements of science and technology, as well as the experience of all member countries of the Eurasian Economic Union.

Federal state fire supervision in respect of products is only carried out at the stage of product sale in the manner prescribed by [10] and is regulated by the provisions of the Administrative Regulations [11].

However, the Administrative Regulations do not regulate the procedure for the control (supervision) of products in circulation, as well as the procedure for the use by the state control (supervision) bodies of the rules and methods of research (tests) and measurements used by the manufacturer (a person who performs the functions of a foreign manufacturer) to confirm the compliance of products released for the first time.

At the same time, by the Decree of the President [12] and the Resolution of the Government of the Russian Federation [13] from 01.11.2011 the powers on accreditation of certification bodies and testing laboratories in the field of fire safety belonging to the Ministry of Emergency Situations of Russia are assigned to the Federal Service for Accreditation.

Accreditation activities and subsequent monitoring of accredited persons by the Federal Accreditation Service are carried out in accordance with [14]. 


\section{Results}

In order to establish effective control (supervision) of products, as well as to exclude the circulation of products in the territory of the Russian Federation that do not meet the mandatory requirements, a set of measures shall be taken to regulate different stages of product circulation [10-17].

For this purpose the following is proposed:

1.Improvement of product control mechanisms.

2.Regulation of product conformity assessment

Within the framework of technical regulation of the processes of development, production and usage of products we propose:

$\bigcirc$ in order to develop a common position on fire safety requirements established by the Technical Regulations [1] and Technical Regulations of the Eurasian Economic Union, to form specialized working groups with the participation of representatives of interested federal executive authorities, product manufacturers and experts from international organizations for the formation of relevant legislation;

$\circ$ development (modification) of international and regional (interstate) standards, and in case of their absence - national (state) standards, as a result of the application of which on a voluntary basis compliance with the requirements of the technical regulations of the Eurasian Economic Union "On the requirements for fire safety and fire-fighting equipment" (TR EAEU 043/2017) is ensured, taking into account the list of international and regional (interstate) standards, and in case of their absence - national (state) standards with rules and methods of research (tests) and measurements, including the sampling rules, which are necessary to meet the TR EAEU 043/2017 requirements;

○ development of national standards regulating the procedure for testing of fire protection systems and their elements.

Let us consider one of the sectors of fire protection products - flame retardants. The basic kinds of discrepancies in terms of the use of certificates and identification of parameters in use are shown in Table 2:

Table 2. Number of certificates of conformity issued by certification bodies accredited in the national accreditation system for the right to carry out works to confirm compliance of products with the requirements of the Federal Law of 22.07.2008 № 123-FZ "Technical Regulations on Fire Safety

Requirements", for the period from 01.01 .2018 to 07.12 .2018 .

\begin{tabular}{|l|l|l|c|c|}
\hline № & $\begin{array}{c}\text { Accreditation } \\
\text { certificate } \\
\text { number }\end{array}$ & Name of the legal entity & $\begin{array}{c}\text { Number of } \\
\text { certificates } \\
\text { of } \\
\text { compliance } \\
\text { issued in } \\
\mathbf{2 0 1 8}\end{array}$ & $\begin{array}{c}\text { Number of } \\
\text { certificates } \\
\text { of } \\
\text { compliance } \\
\text { issued in } \\
\mathbf{2 0 1 7}\end{array}$ \\
\hline & RA.RU.10CHS13 & $\begin{array}{l}\text { FGBU VNIIPO EMERCOM of } \\
\text { Russia }\end{array}$ & 245 & 336 \\
\hline & RA.RU.11PB97 & $\begin{array}{l}\text { FGBU AGPS EMERCOM of } \\
\text { Russia }\end{array}$ & 220 & 326 \\
\hline & TRP.RU.11AZH45 & $\begin{array}{l}\text { FGBOU SPb UGPS EMERCOM of } \\
\text { Russia }\end{array}$ & 23 & 17 \\
\hline & $\begin{array}{l}\text { "Fire Safety Technologies" Ltd } \\
\text { (accreditation certificate is } \\
\text { terminated) }\end{array}$ & 6 & 599 \\
\hline RU.0001.11PB71 & "NEW TECHNOLOGIES" Ltd & 53 & 47 \\
\hline TRPB.RU.PB57 & $\begin{array}{l}\text { PozhStandard Ltd } \\
\text { (accreditation certificate }\end{array}$ & 202 & 535 \\
\hline
\end{tabular}




\begin{tabular}{|c|c|c|c|}
\hline & suspended) & & \\
\hline TRPB.RU.PB58 & $\begin{array}{l}\text { "Alpha" Fire Safety Limited } \\
\text { Liability Company }\end{array}$ & 319 & 437 \\
\hline RA.RU.10AYU64 & $\begin{array}{l}\text { Autonomous non-profit } \\
\text { certification organization } \\
\text { "Electrosert" }\end{array}$ & 267 & 379 \\
\hline $\begin{array}{l}\text { ROSS } \\
\text { RU.0001.11PB68 }\end{array}$ & Fire Certification Company Ltd & 205 & 416 \\
\hline TRPB.RU.PB09 & $\begin{array}{l}\text { Autonomous Non-Commercial } \\
\text { Organization "Firefighters of } \\
\text { Moscow Region Certification } \\
\text { Center" }\end{array}$ & 71 & 57 \\
\hline TRPB.RU.PB37 & NPO POZHTSENTER Ltd & 236 & 214 \\
\hline TRPB.RU.PB34 & $\begin{array}{l}\text { SCIENTIFIC TECHNICAL } \\
\text { CENTER "POZH-AUDIT" Ltd }\end{array}$ & 257 & 167 \\
\hline TRPB.RU.PB74 & $\begin{array}{l}\text { North-West Permit Center for Fire } \\
\text { Safety Ltd }\end{array}$ & 55 & 274 \\
\hline TRPB.RU.PB21 & Center of Fire Expertise Ltd & 52 & 37 \\
\hline RA.RU.11KB02 & $\begin{array}{l}\text { Independent Research Testing } \\
\text { Center Ltd }\end{array}$ & 6 & 2 \\
\hline RA.RU.11ME80 & $\begin{array}{l}\text { Autonomous non-commercial } \\
\text { organization Secab Center for } \\
\text { Cable Products Certification" }\end{array}$ & 20 & 18 \\
\hline $\begin{array}{l}\text { ROSS } \\
\text { RU.0001.11EO31 }\end{array}$ & LANTA CENTER Ltd & 268 & 474 \\
\hline RA.RU.11ST08 & $\begin{array}{l}\text { Moscow Regional Public Institution } \\
\text { - REGIONAL CERTIFICATION } \\
\text { CENTER "Opytnoye" }\end{array}$ & 16 & 15 \\
\hline RA.RU.11PB26 & $\begin{array}{l}\text { Tomsk certification and } \\
\text { management center Ltd }\end{array}$ & 16 & 20 \\
\hline RA.RU.11PB65 & Transconsulting Ltd & 33 & 24 \\
\hline RA.RU.11AZH03 & Optikenergo Test Center Ltd & 32 & 16 \\
\hline RA.RU.11KB03 & $\begin{array}{l}\text { Complex Safety Scientific and } \\
\text { Testing Center Ltd }\end{array}$ & 197 & 250 \\
\hline RA.RU.11AB09 & $\begin{array}{l}\text { Southern Register-Center of } \\
\text { Expertise of Fire Safety in } \\
\text { Construction Ltd }\end{array}$ & 355 & 153 \\
\hline RA.RU.11AB03 & $\begin{array}{l}\text { NORMATEST Conformity } \\
\text { Assessment Centre Ltd }\end{array}$ & 53 & 60 \\
\hline RA.RU.10AD63 & $\begin{array}{l}\text { Stroytrest Independent Testing and } \\
\text { Expert Center Ltd }\end{array}$ & 26 & - \\
\hline $\begin{array}{l}\text { ROSS } \\
\text { RU.0001.11EO30 }\end{array}$ & $\begin{array}{l}\text { Closed Joint-Stock Company } \\
\text { OGNESTOYKOST Certification } \\
\text { and Testing Center }\end{array}$ & 120 & 103 \\
\hline RA.RU.10AD67 & Bickwest Center Ltd & 26 & 1 \\
\hline & Total & 3379 & 4977 \\
\hline \multicolumn{2}{|c|}{$\begin{array}{l}\text { Total number of certificates by organizations subordinate } \\
\text { to the Russian Ministry of Emergency Situations }\end{array}$} & $488(14.4 \%)$ & $679(13.6 \%)$ \\
\hline \multicolumn{2}{|c|}{ By non-affiliated organizations } & $\begin{array}{c}2891 \\
(85.6 \%) \\
\end{array}$ & $\begin{array}{c}4298 \\
(86.4 \%) \\
\end{array}$ \\
\hline
\end{tabular}

Thus, certification centers carry out tests not in accordance with GOST and issue obligatory certificates instead of voluntary ones. 


\section{Conclusions}

As part of the regulation by the Russian Ministry of Emergency Situations of the issues of verification of conformity of products to mandatory requirements, it is proposed [20-22]:

- elaboration of the issue of introduction of notification mechanisms for certification bodies verifying the compliance of fire-technical products intended for social protection, health care and education facilities, as well as unique facilities and those critical for the national security of the Russian Federation, in order to improve their fire safety;

- consideration of the possibility of creating on the basis of FGBU VNIIPO of the Ministry of Emergency Situations of Russia a provider of interlaboratory comparative tests for verifying the compliance of products with the requirements of the Technical Regulations.

- concluding an agreement between the Ministry of Emergency Situations of Russia and the Federal Accreditation Service regarding the exchange of information on detected violations in confirming the compliance of products with fire safety requirements and taking appropriate measures; concluding an agreement with organizations for the protection of consumer rights; creating a unified register for the exchange of information on detected violations in confirming the compliance of products with fire safety requirements.

In order to improve the mechanisms of control (supervision) of products the following is proposed:

- elaboration of the issue of product supervision as a separate state function with the development and establishment of appropriate administrative procedures;

- providing at the legislative level for the implementation of the "Control purchase", which will allow to conduct research (testing) of products without appropriate procedures for its withdrawal from the owner;

- developing and maintaining an electronic register of identification parameters, defined, in particular, by means of instrumental control methods, of products that have undergone the procedure of conformity assessment and are circulating on the territory of the Russian Federation;

- establishing departments in the supervision offices of the Main Departments of the Ministry of Emergency Situations of the Russian Federation for the subjects of the Russian Federation (with the introduction of appropriate changes to the provisions of the territorial structural subdivisions), for organizing and coordinating product control and inspections of products.

\section{References}

1. Federal Law of Russian Federation No. 123-FZ (2008)

2. The SFPE Handbook of Fire Protection Engineering (NFPA, 2002)

3. International Standard ISO 23932 (2018)

4. C.A. Wade, S.J. Callaghan, G.S. Strickland, A.F. Bennett, Investigation of Methods and Protocols for Regulating the Fire Performance of Materials with Applied Fire Retardant Surface Coatings, http://www.firesciencereviews.com/content/2/1/4

5. J.I. Lataille, Fire protection engineering in building design (Elsevier Science, Butterworth-Heinemann, Oxford, 2003)

6. Eurocode guidance paper $l$ (concerning the construction products directive 89/106/EEC) (Brussels, 2003)

7. International Standard DIN EN 13501-1-2019

8. Federal Law of Russian Federation No. 184-FZ (2002) 
9. The order of the Government of Russian Federation No. 304-r (2009)

10. Federal Law of Russian Federation No. 294-FZ (2008)

11. Administrative regulations of the Ministry of the Russian Federation No. 644 (2016)

12. Decree of the President of the Russian Federation No. 86 (2011)

13. Decree of the Government of the Russian Federation No. 845 (2011)

14. Federal Law of of Russian Federation No. 412-FZ (2013)

15. R. Abdrashitova, Technical regulations as the basis for the single policy in the field of compliance with product quality requirements in Russian Federation 3, 21-25 (2018)

16. V. Kashui, Materials of the I Interregional Scientific and Practical Conference, 45-48 (2018)

17. A. Generozova, Materials of Russian scientific conference with international participation, 315-318 (2017)

18. A. Strekalev, E. Mizina, T. Borovikova, T. Egorova, What you need to know when buying fire-fighting technical products, http://www.secuteck.ru/articles2/firesec/chtonuzhno-znat-pri-pokupke-pozharno-tehnicheskoy-produktsii

19. S. Gryaznov, A. Dymkov, A. Starostin, Civil Protection Strategy: Issues and Research, 7.2(13), 70-82 (2017)

20. V.A. Markeev, S.S. Voevoda, D.A. Korolchenko, Oil Industry 9, 83-85 (2006)

21. Iu. Polandov, D. Korolchenko, MATEC Web of Conferences 106, 01040 (2017) DOI: $10.1051 /$ matecconf $/ 201710601040$

22. D. Korolchenko, V. Kholshchevnikov, MATEC Web of Conferences 106, 01038 (2017) DOI: 10.1051/matecconf/201710601038. 